\title{
PERAN TUMOR ASOCIATED MACROPHAGE (TAM) \\ PADA KANKER PAYUDARA
}

\author{
Hilda Taurina \\ Fakultas Kedokteran dan IImu Kesehatan Universitas Bengkulu \\ Email : hildataurina@gmail.com
}

\begin{abstract}
ABSTRAK
Kanker payudara adalah salah satu kanker yang banyak ditemukan di dunia. Makrofag yang dijumpai pada kanker dikenal dengan istilah Tumor Asociated Macrophage (TAM) yang meliputi fenotip makrofag M1 dan M2. Kedua fenotip ini mempunyai fungsi yang berlawanan.
\end{abstract}

Kata Kunci : Kanker payudara, Makrofag M1, Makrofag M2

\section{ABSTRACK}

Breast cancer is one of the cancers that are found in the world. Macrophages are found in cancer known as Tumors Asociated Macrophage (TAM), which includes M1 and M2 macrophage phenotype. The second phenotype has the opposite function in breast cancer.

Keyword : Breast cancer, M1 macrophage, M2 macrophage

\section{PENDAHULUAN}

Kanker merupakan salah satu penyakit tidak

menular yang menjadi permasalahan kesehatan

utama di dunia. Menurut Badan Kesehatan

Dunia $(W H O)$ pada tahun 2008 dilaporkan 8,2

juta orang meninggal karena kanker. Kasus

kanker baru yang terjadi di negara berkembang

mencapai sekitar $50 \%$ dan $60 \%$ kasus kematian

disebabkan oleh kanker. ${ }^{2}$ Kanker merupakan

penyebab kematian utama disamping penyakit

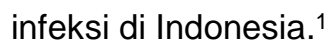

Kanker terbentuk akibat pertumbuhan sel yang

rusak, terjadinya melalui beberapa tahapan yaitu hiperplasia, displasia, dan neoplasia. Pada

hiperplasia keadaan sel tumbuh dalam jumlah

yang berlebihan. Displasia merupakan kondisi

ketika sel berkembang tidak normal dan pada

umumnya terjadi perubahan pada nukleusnya.

Pada tahapan ini, ukuran nukleus bervariasi,

aktivitas mitosis meningkat, tetapi tidak

ditemukan ciri-ciri sitoplasma yang berhubungan

dengan diferensiasi sel. Neoplasia merupakan

kondisi sel pada jaringan yang sudah

berproliferasi secara berlebihan dan memiliki

sifat invasif. ${ }^{3}$ 


\section{KANKER PAYUDARA}

Kanker payudara merupakan penyakit genetik kompleks yang masih menjadi masalah utama di bidang kesehatan, baik di negara berkembang maupun negara maju. Penderita kanker payudara lebih banyak pada wanita, dengan proporsi $27.5 \% .^{5}$

Kanker payudara dapat dibedakan menjadi beberapa tipe, yaitu ductal (adeno)carcinoma, lobular (adeno)carcinoma dan Paget's disease of the nipple (Gambar 1). Ductal (adeno)carcinoma merupakan tipe kanker payudara yang berasal dari epitel duktus. Lobular (adeno)carcinoma berasal dari epitel lobulus. Paget's disease of the nipple berasal dari ductal carcinoma di dalam duktus laktiferus dan menyebar melalui sel epidermis puting susu. ${ }^{4}$ Kanker payudara berasal dari jaringanithel dan paling sering terjadi pada sistem duktal. Kanker payudara diawali dengan terjadinya hiperplasia dengan perkembangan sel-sel atipik. Sel-sel ini akan berlanjut menjadi karsinoma in situ dan menginvasi stroma.

Sebanyak 1-2\% wanita dengan kanker payudara mempunyai gejala mirip dengan infeksi payudara akut, yaitu kulit menjadi merah, panas, edema, dan nyeri. Fenomena tersebut dikenal sebagai inflamasi karsinoma, yaitu tumor yang tumbuh dengan cepat,menginvasi kulit dan jaringan limfa. Karsinoma payudara dapat menyebar (metastasis) ke jaringan sekitar melalui saluran limfa dan aliran darah. Organ yang paling sering menjadi tujuan metastasis adalah paru, pleura, dan tulang.

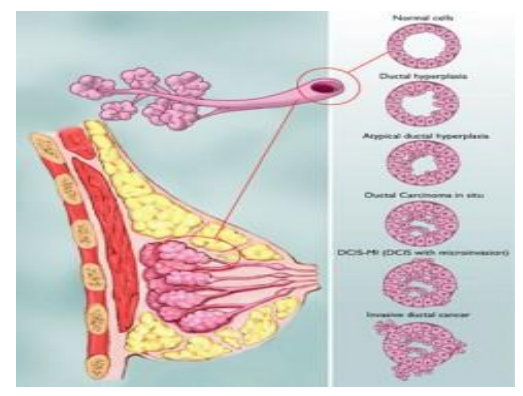

Gambar 1. Jenis-jenis kanker (Hagedoorn et al., 1994) 
RESPON IMUN PADA TUMOR DAN PERAN

TAM

\author{
Respon imun terhadap sel tumor \\ diperantarai oleh sel T sitotoksik (T CD8+) yang \\ spesifik terhadap antigen tumor. Aktivasi sel $\mathrm{T}$ \\ CD8+ ini tidak hanya membutuhkan perantara \\ kompleks histokompatibilita Major \\ Histocompatibility Complex (MHC) kelas I saja \\ namun juga membutuhkan kostimulasi dari MHC \\ kelas II (sel T CD4+). ${ }^{6}$
}

Makrofag melakukan fungsinya sebagai

sistem imun dengan cara fagositosis bakteri yang masuk ke dalam tubuh. Proses fagositosis

terjadi dengan cara mengelilingi, kemudian

memakan dan menghancurkan antigen tersebut,

proses ini merupakan bagian dari reaksi

peradangan. Makrofag juga mempunyai peran

yang penting dalam imun adaptif, dalam hal ini

makrofag akan mengambil antigen dan

mengantarkannya untuk dihancurkan oleh

komponen-komponen imun lain dalam sistem imun adaptif. TAM berasal dari diferensiasi monosit dan menuju ke lokasi tumor oleh aktivitas kemotaktik (kemokin) yaitu CCL2/MCP17. Kebanyakan karsinoma manusia menghasilkan CCL2. Kadar dan ekspresi CCL2 berkorelasi dengan kenaikan infiltrasi makrofag (Conti I dan Rollins, 2004). Pada kanker payudara dan kanker esofagus manusia, kadar CCL2 berkorelasi dengan perluasan infiltrasi makrofag, metastasis limfonodus dan agresifitas klinis . Chemokine (C-C motif) Ligand 2/ CCL2 berperan dalam perkembangan tumor, dengan cara menstimulasi pertumbuhan neoplastik, memicu reaksi radang dan menginduksi angiogenesis. Makrofag juga direkrut ke lokasi tumor oleh suatu sitokin yang dihasilkan oleh tumor yang berinteraksi dengan reseptor tirosinkinase, seperti vascular endothelial growth factor (VEGF) dan macrophage colony stimulating factor (M-CSF) (Gambar 2). ${ }^{8}$ 


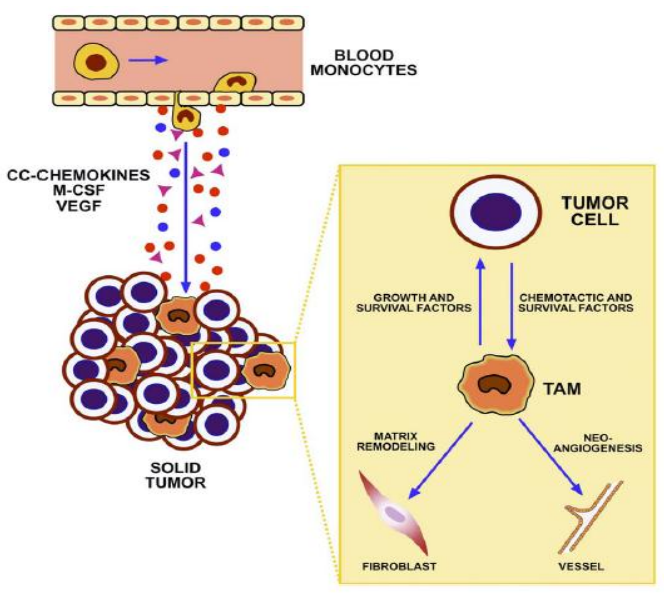

Gambar 2. Hubungan antara makrofag dan sel tumor (Antonio et al., 2006)

Diferensiasi makrofag tergantung pada induksi sitokin yang diterimanya. Aktivasi makrofag terdiri atas aktivasi klasik atau yang dikenal dengan aktivasi makrofag M1 dan aktivasi alternatif yang dikenal dengan aktivasi makrofag M2. Makrofag M1 diinduksi oleh PAMPs dan IFN-y. IFN-Y yang dapat mengaktivasi makrofag dihasilkan oleh sel NK serta sel Th1 $.9,10,11$

Fenotip makrofag M1 dapat diinduksi oleh adanya stimulus dari IFN- $y$ dan TNF- $\alpha$ ataupun akibat adanya induksi produk mikroba, seperti lipopolysaccharide (LPS) (Gambar 3). Pada sel M1 terjadi peningkatan molekul permukaan seperti MHC kelas II dan B-7 (CD86) sehingga memiliki kemampuan untuk melakukan presentasi antigen. Makrofag M1 juga memiliki kemampuan untuk membunuh patogen ${ }^{6}$.
Kemampuan makrofag M1 dalam membunuh patogen meningkat dengan adanya induksi dari inducible NO synthase (iNOS) untuk memproduksi nitric oxide (NO). Makrofag M1 menggunakan arginin sebagai substrat untuk membentuk inducible nitric oxide synthase (iNOS) dan menghasilkan nitrit oksida yang bersifat mikrobisidal ${ }^{10,11}$. Makrofag M2 merupakan makrofag yang bersifat antiinflamasi dan dapat diinduksi oleh IL-4 dan IL-13 yang dihasilkan oleh sel Th2 (Gambar 3) 9,10,11. M2 menghasilkan beberapa sitokin antiinflamasi seperti IL-10 dan interleukin-1 receptor antagonist (IL-1RA). Makrofag M2 merupakan fenotip makrofag yang tidak efektif dalam presentasi antigen, meskipun menunjukkan adanya peningkatan molekul MHC kelas II ${ }^{6}$. Makrofag M2 menggunakan arginin sebagai 
substrat untuk arginase 1 (Arg1), kemudian pertumbuhan sel dan pembelahan sel, mendegradasi arginine menjadi ornithine, yang sedangkan prolin merupakan komponen utama merupakan prekursor untuk poliamin, prolin, dan dari kolagen. Oleh karena itu makrofag tipe ini kolagen yang dibutuhkan untuk proses lebih cenderung bersifat sebagai regulator dan perbaikan jaringan. Poliamin terlibat dalam pemulih daripada sebagai sel efektor 10,11 .

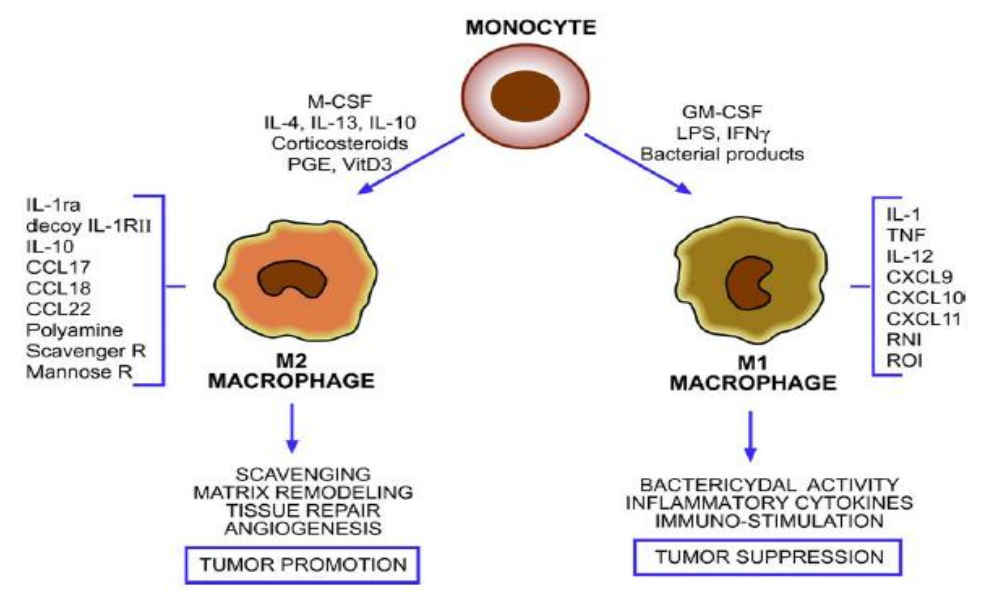

Gambar 3. Fenotip dan fungsi makrofag (Antonio et al., 2006)

Pada kanker, makrofag M2 berperan untuk meningkatkan kelangsungan hidup dan kapasitas proliferasi sel kanker, memacu motilitas, intravasasi, dan sifat invasif sel kanker, meningkatkan angiogenesis, memediasi imunosupresi, dan reorganisasi matriks ekstraseluler (Gambar 4).

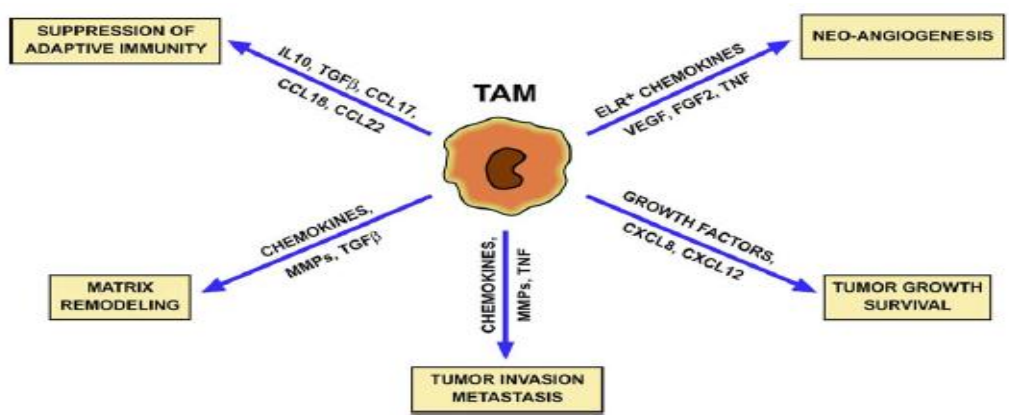


Gambar 4. Fungsi TAM sebagai protumoral (Antonio et al., 2006)

\section{KESIMPULAN}

Peran fenotip makrofag M2 pada karsinoma payudara adalah sebagai pemicu (promotor) pertumbuhan karsinoma sedangkan peran fenotip makrofag M1 adalah sebagai penekan karsinoma (supresi).

\section{DAFTAR PUSTAKA}

1. Tjindarbumi D, dan Mangunkusuma R, 2002, Cancer in Indonesia, Present and Future, JpJ Clin Oncol,32 (Supplement 1), 17-21.

2. Shibuya K, Mathers CD, Boschi-Pinto C, Lopez AD, Murray CJL, 2002. Global and regional estimates of cancer mortality and incidences by site: II. Results for the global burden of disease 2000.BMC Cancer, 2(37).

3. Sander M, Trump BF, and Tennant RW, 2008, The $20^{\text {th }}$ aspen cancer conference; mechanism of toxicity, carcinogenesis, cancer prevention and cancer therapy, Mol Carcinog, 47(9):707732.
4. Hagedoorn EML, Oldhoff J, Bender W, 1994, Essential oncology for heallth professionals, Van Gurcum, Assen : 53-70.

5. Pazdur R, Wagmn LD, Camphausen KA, and Hoskins WJ, 2009, Cancer Management: $A$ Multidiciplinary Approach, $12^{\text {th }}$ edition, CMP Medica: America.

6. Antonio Sica, Tiziana Schiopp, Alberto Mantovani, Paola Allavena. Tumourassociated macrophages are a distinct M2 polarised population promoting tumour progression. Potential targets of anti-cancer therapy. EJC 42 (2006) $717-727$.

7. Matsushima K., Larsen CG, DuBois GC, Oppenheim JJ. Purification and characterization of a novel monocyte chemotactic and activating factor produced by a human myelomonocytic cell line. J Exp Med 1999;169:1485-90.

8. Duyndam MC, Hilhorst MC, Schluper HM. Vascularendothelial growth factor-165 overexpression stimulatesangiogenesis and induces cyst formation and macrophageinfiltration in human ovarian 
cancer xenografts. Am $J$ Pathol 2002;160:537-48.

9. Gordon S. Alternative activation of macrophages. Nat Rev Immunol 2003;3:2335.

10. Mosser DM. The many faces of macrophage activation. J Leukoc Biol 2003;73:209-12.

11. Moon ML, McNeil LK, Freund GG. 2011. Macrophages make me sick how macrophage activation states influence sickness behavior Psychoneuroendocrinology, $36: 1431-4$ 
Jurnal Kedokteran Raflesia Volume 2 Nomor 2, Desember 2016 